\title{
Poznámka úvodem
}

V nejnovějším svazku sborníku Praehistorica je zveřejněna práce Mgr. Lindy Hroníkové, Ph.D., věnovaná poměrně netradiční a atraktivní problematice. Autorka představuje teoretická východiska mikroskopické analýzy pracovních stop na ostřích kamenných štípaných artefaktů (tzv. traseologie) i konkrétní výsledky vlastních traseologických výzkumů. Přestože od prvního aplikování metody ruským archeologem Sergejem Aristarchovičem Semjonovem uplynulo více než padesát let, neměla česká archeologie dosud př́liš mnoho př́ležitostí sledovat aplikaci uvedené metody na domácím materiálu. Málokterý z badatelů zaznamenal, že před lety provedla traseologickou analýzu na vybraných artefaktech z neolitického sídlišstě v Bylanech u Kutné Hory anglická badatelka Ruth Tringham.

V devadesátých letech jsem se rovněž snažil prosadit aplikaci mikroskopické analýzy pracovních stop v českém prostředí. S pomocí kolegů Heleny a Kjela Knuttson ze švédské Uppsaly a s přispěním Švédského institutu ve Stockholmu jsem absolvoval třítýdenní intenzivní kurz traseologie. Za tu krátkou dobu jsem porozuměl smyslu metody a uvědomil si značnou výši nákladů na nezbytné př́strojové vybavení - kvalitní badatelský mikroskop s průchozím světlem a mikrofotozařízení pro pořizování fotodokumentace. Rovněž jsem poměrně brzy pochopil, že analýza tohoto typu je „během na velmi dlouhé trati“".

Kvalitou odpovídající mikroskop byl k dispozici v chemické laboratoři Archeologického ústavu AV ČR v Praze, mikrofotoaparát jsem získal díky grantové podpoře GAČR, bohužel z prostředků, poskytnutých na nákup fotoaparátu až do třetího roku projektu. Každou možnou chvíli jsem navštěvoval pracoviště s mikroskopem a snažil se o pořizování fotodokumentace jak originálních pravěkých artefaktů, tak artefaktů z vlastních experimentů. $\mathrm{S}$ přibývajícími zkušenostmi ovšem úměrně rostlo přesvědčení, že traseologie není jen krátká epizoda v profesním životě archeologa, ale jediný dlouhodobý vědecký záměr.

Povodeň v létě roku 2002 odnesla nejen veškeré vybavení chemické laboratoře Archeologického ústavu včetně mikroskopu, fotoaparátu a dalších důležitostí, ale i naději na možnost odpovědně se soustředit na traseologickou analýzu. Zůstalo jen pár fotografí́, experimentální nástroje, vzpomínka na panenskou př́rodu Skandinávie a trochu zklamání nad nenaplněnými plány...

O to víc editory těší, že v tomto svazku Praehistorica se daří zveřejnit studii Lindy Hroníkové, která je věnována nejen podrobnému a srozumitelnému teoretickému vysvětlení traseologické analýzy, ale hlavně konkrétní analýze štípaných artefaktů ze čtyř neolitických sídlišst v Čechách. Autorka není školená archeoložka, studovala na Fakultě humanitních studiích v Praze, ale její specializace ji s archeologií pevně spojuje a výsledky jejích traseologic- 
kých výzkumů jsou nyní k dispozici a doufejme, že především do budoucnosti budou obohacovat českou archeologickou literaturu o poznatky, které prohlubují naše poznání ekonomických aktivit společností doby kamenné. Linda Hroníková absolvovala delší studijní pobyt v Nizozemí pod vedením jedné z uznávaných odbornic na aplikaci traseologické metody - Annelou van Gijn na univerzitě v Leidenu a můžeme ji tedy považovat za osobu velmi kompetentní.

Nebudeme proto hodnotit rozsah a úroveň nezbytných archeologických informací, které autorka v práci využila, ale soustředíme se v hodnocení zejména na výsledky autorčiných experimentů i samotné analýzy pracovních stop. Při vzpomínce na vlastní pozorování v mikroskopu v chemické laboratoři Archeologického ústavu musím přiznat, že obdivuji trpělivost a úsilí Lindy Hroníkové, která pro tuto studii využila k analýze více než 800 kamenných artefaktů! Představuje to nekonečné hodiny nad okuláry mikroskopu, kdy oči již odmítají spolupracovat, kdy pracovní stopy zdánlivě neexistují a kdy sebemenší otřes z okolí naprosto znehodnotí úroveň mikrofotografie...

V Praze v červnu 2011

Miroslav Popelka 